\title{
PENGARUH PEMBERIAN BERBAGAI KULIT JERUK SEBAGAI REPELENSI KUTU BERAS (Sitophilus oryzae L.) DAN SUMBANGSIHNYA PADA MATERI HAMA DAN PENYAKIT PADA TANAMAN DIKELAS VIII
}

\author{
Desma Susanti $^{1 \text { a) }}$, Choirun Niswah ${ }^{2)}$, Riri Novi Sunarti ${ }^{3)}$ \\ 1) Program Studi Pendidikan Biologi, Fakultas Ilmu Tarbiyah dan Keguruan, UIN Raden Fatah, \\ Jl. Prof. K.H Zainal Abidin Fikri No. IA KM. 3,5 30126, Indonesia \\ ${ }^{2)}$ Program Studi Pendidikan Agama Islam, Fakultas Ilmu Tarbiyah dan Keguruan UIN Raden Fatah \\ Jl. Prof. K.H Zainal Abidin Fikri No. IA KM. 3,5 30126, Indonesia \\ ${ }^{3)}$ Program Studi Biologi, Fakultas Sains dan Teknologi, UIN Raden Fatah Palembang, \\ Jl. Prof. K.H Zainal Abidin Fikri No. IA KM. 3,5 30126, Indonesia \\ ${ }^{a)}$ E-mail: desmasusanti10@gmail.com \\ Telp: +62-813-7393-6947
}

\begin{abstract}
This study entitled the effect of giving various orange peels as a repelence of rice lice (Sitophillus oryzae L.) and its contribution to pest and disease material in plants in class VIII. This study aims to determine the effectiveness of various orange peels as a repelence of what type of rice lice and orange skin is most effectively used as a repelence of rice lice. The type of research used in this study is quantitative descriptive research (where the data collection process uses statistical analysis) and the experimental method. The data obtained were analyzed statistically using Analysis of Varience (ANOVA). Analysis of the variance of the treatment effects for a complete randomized design (CRD) was carried out according to the F test. Based on the results of the research, each treatment was significantly different from the control. The highest percentage of rejection was found in the treatment of lime peel, which amounted to 56.25 at 76 hours and the lowest percentage was found in the treatment of sunkist orange peel ie 27.5 at 76 hours. Hypothesis testing results for F count treatment (19>1.79) and F count Factor A (40>2.99) and F count on Factor B (102> 3.20), this states that slices of various orange peels (Citrus sp.) very significant effect to reject rice infestation (Sitophillus oryzae L.), so that it is stated that $\mathrm{H} 1$ is accepted and H0 is rejected. Thus it can be concluded that various citrus coolies are effective as repelensi rice mites (Sitophillus oryzae L.).
\end{abstract}

Keywords : Various orange peels, repelence, rice lice (Sitophillus oryzae)

\begin{abstract}
ABSTRAK
Penelitian ini berjudul pengaruh pemberian berbagai kulit jeruk sebagai repelensi kutu beras (Sitophillus oryzae L.) dan sumbangsihnya pada materi hama dan penyakit pada tanaman di kelas VIII. Penelitian ini bertujuan untuk mengetahui efektivitas berbagai kulit jeruk sebagai repelensi kutu beras dan kulit jeruk jenis apa yang paling efektif digunakan sebagai repelensi kutu beras. Jenis penelitian yang digunakan pada penelitian ini yaitu penelitian deskriptif kuantitatif (yang mana proses pengumpulan datanya menggunakan analisis statistik) dan dengan metode eksperimen. Data yang diperoleh dianalisis secara statistik menggunakan Analisis of Varience (ANOVA). Analisis sidik ragam pengaruh perlakuan untuk rancangan acak lengkap (RAL) dilakukan menurut uji F. Berdasarkan hasil penelitian masing-masing perlakuan berbeda nyata dengan kontrol. Persentase penolakan tertinggi terdapat pada perlakuan kulit jeruk nipis yaitu sebesar 56,25 pada waktu 76 jam dan persentase terendah terdapat pada perlakuan irisan kulit jeruk sunkist yaitu sebesar 27,5 pada waktu 76 jam. Hasil pengujian hipotesis untuk F hitung perlakuan $(19>1,79)$ maupun F hitung Faktor A $(40>2,99)$ dan F hitung pada Faktor B ( $102>3,20)$, hal ini
\end{abstract}


menyatakan bahwa irisan berbagai kulit jeruk (Citrus sp.) berpengaruh sangat nyata untuk menolak kutu beras (Sitophillus oryzae L.), sehingga dinyatakan bahwa $\mathrm{H}_{1}$ diterima dan $\mathrm{H}_{0}$ ditolak. Dengan demikian dapat disimpulkan bahwa berbagai kuli jeruk efektif sebagai repelensi kutu beras (Sitophillus oryzae L.).

Kata kunci: Berbagai kulit jeruk, repelensi, kutu beras (Sitophillus oryzae)

\section{PENDAHULUAN}

Beras merupakan bahan pangan pokok bagi $90 \%$ penduduk Indonesia. Berdasarkan jenisnya beras dapat dibagi menjadi beras putih, beras merah, beras ketan hitam dan beras ketan putih. Beras merupakan bahan pangan utama sebagai sumber karbohidrat bagi sebagian besar masyarakat Indonesia. Petani biasanya pada saat panen menyimpan berasnya digudang. Selama masa penyimpanan beras yang disimpan akan mengalami kerusakan dan penyusutan baik secara kuantitas maupun kualitas. Salah satu penyebab menurunnya kuantitas dan kualitas hasil panen yang disimpan adalah serangan dari hama gudang. Salah satu hama gudang yang menyerang hasil panen adalah Sitophilus oryzae (Kumbang beras). (Yudansha dkk, 2013).

Dua spesies Sitophilus (S.oryzae, $S$. zeamais, Coleptera: Curculionidae) merupakan hama utama yang merusak komoditas pertanian pertanian dipenyimpanan seperti gandum, jagung, dan beras (Campbell, 2002) “ dalam” (Hendrival dan Lilis, 2017). Hama kumbang bubuk beras (Sitophilus oryzae L.) tergolong sebagai hama primer yang mampu menyerang biji utuh. Serangga dewasa dan larva $S$. oryzae merusak biji-bijian dengan memakan karbohidrat dalam butiran biji sehingga terjadi penurunan susut berat pangan dan konstaminasi produk, mengurangi viabilitas benih, menurunkan nilai pasar, dan mengurangi nilai gizi (Ashamo, 2006) "dalam” Hendrival dan Lilis (2017).

Penggunaan pestisida akan semakin meningkat sejalan dengan meningkatnya kebutuhan produk pertanian. Untuk menghasilkan produk pertanian yang mencukupi, maka setiap Organisme Pengganggu Tumbuhan (OPT) harus dilakukan secara bijaksana, apalagi pada era pertanian yang sehat (back to nature) yang lebih mementingkan produk berkualitas dan bebas dari cemaran, baik hayati maupun kimia. Produk pertanian yang sehat dan ramah lingkungan sudah merupakan tuntunan pasar global (AFTA, APEC, dan WTO), dengan label ramah lingkungan (eco-labeling attributes), bernutrisi tinggi (nutritional attributes), dan aman dikonsumsi (food safety attributes) (Wirdianti, 2015).

Peraturan Pemerintah (PP) No. 6 tahun 1995 pasal 3 ditetapkan bahwa perlindungan tanaman dilaksanakan melalui sistem Pengendalian Hama Terpadu (PHT); selanjutnya dalam pasal 19 dinyatakan bahwa penggunaan pestisida dalam rangka pengendalian Organisme Pengganggu 
Tumbuhan (OPT) merupakan alternatif terakhir dan dampak yang ditimbulkan harus ditekan seminimal mungkin. Oleh karena itu, perlu dicari cara pengendalian yang efektif terhadap hama sasaran namun aman terhadap organisme bukan sasaran dan lingkungan. Salah satu golongan pestisida yang memenuhi persyaratan tersebut adalah pestisida yang berasal dari tumbuh-tumbuhan (insektisida nabati) (Martono, dkk. 2004) "dalam" Wirdianti, 2015.

Insektisida nabati merupakan bahan aktif tunggal atau majemuk yang berasal dari tumbuhan yang bisa digunakan untuk mengendalikan organisme pengganggu. insektisida nabati ini bisa berfungsi sebagai penolak, penarik, antifertilitas (pemandul), pembunuh, dan bentuk lainnya. Secara umum, insektisida nabati diartikan sebagai suatu insektisida yang bahan dasarnya dari tumbuhan yang relatif mudah dibuat dengan kemampuan dan pengetahuan terbatas. Sifat dari insektisida nabati umumnya tidak berbahaya bagi manusia ataupun lingkungan serta mudah terurai dibandingkan dengan insektisida sintetik (Kardinan, 2001) "dalam" Wirdianti, 2015. Pada umumnya insektisida nabati dapat dibuat dengan teknologi yang sederhana atau secara tradisional yaitu : pengerusan, penumbukan, pembakaran, atau pengepresan. Disamping itu insektisida nabati pada umumnya kurang stabil dalam penyimpanan, sehingga jangka waktu sejak pembuatan sampai dengan penggunaan diusahakan sesingkat mungkin.
Insektisida nabati dapat diperoleh atau dihasilkan oleh tumbuhan yang mudah dijumpai dalam kehidupan sehari-hari. Seperti daun sirih, tanaman jeruk dan lain- lain. Seperti penelitian yang akan dilakukan ini, disini yang akan dijadikan sebagai insektisida atau pestisida yaitu kulit jeruk.

Jenis minyak atsiri jeruk dibedakan berdasarkan varietasnya karena kulit jeruk yang tersedia cukup banyak yaitu kulit jeruk manis, jeruk besar, jeruk siam, jeruk siam madu, jeruk purut, jeruk nipis, dan jeruk keprok. Semua kulit jeruk dapat diambil atau diekstrak minyak atsirinya (Prastiwi dan Ferry, 2016).

Kulit jeruk mengandung minyak atsiri yang terdiri dari berbagai golongan senyawa seperti terpen, sesquiterpen, aldehida, ester dan sterol. Kulit jeruk memiliki kandungan senyawa yang berbeda-beda, bergantung varietas, sehingga aromanya pun berbeda. Namun, senyawa yang dominan adalah limonene (C10H16). Kandungan limonene bervariasi untuk tiap varietas jeruk, berkisar antara 70-92\%. Rincian komponen minyak kulit jeruk adalah sebagai berikut: limonene $94 \%$, mirsen $2 \%$, linalol 0,5\%, oktanal $0,5 \%$, dekanal $0,4 \%$, sitronelal $0,1 \%$, neral $0,1 \%$, geranial $0,1 \%$, valensen $0,05 \%, \beta$-sinensial $0,02 \%$, dan $\alpha$-sinensial $0,01 \%$ (Prastiwi dan Ferry, 2016).

Grainge et al., (1985) "dalam" (Wirdianti, 2015), melaporkan bahwa ada lebih dari 1000 spp. tumbuhan yang mengandung insektisida, lebih dari 380 spp. 
113 Bioilmi Vol. 4 No. 2 Edisi Juli-Desember Tahun

mengandung zat penghambat pertumbuhan. Berdasarkan hal tersebut, maka potensi bahan nabati untuk pengendalian organisme penganggu tanaman cukup besar (Martono, 2010), “dalam" Wirdianti, 2015.

Terdapat banyak jenis tumbuhan yang memang diciptakan untuk menjadikan manusia berfikir bagaimana cara pemanfaatannya. Allah berfirman dalam surat Q.S Asy - Syua'ra: ayat 7 :

Artinya : "Dan apakah mereka tidak memperhatikan bumi, berapakah banyaknya Kami tumbuhkan di bumi itu berbagai macam tumbuh-tumbuhan yang baik?" (Q.S Asy Syua'ra: ayat 7).

Berdasarkan ayat tersebut, dapat diketahui bahwa Allah menciptakan berbagai macam tumbuhan yang baik, artinya tumbuhan tersebut berguna untuk kehidupan manusia tidak terkecuali kulit jeruk. Selain memiliki aroma yang tidak disukai nyamuk kulit jeruk juga memiliki potensi untuk menjadi zat pengusir atau repellent terhadap hama pada beras seperti Sitophilus oryzae L.

\section{METODOLOGI PENELITIAN}

Penelitian ini dilaksanakan pada tanggal 23 September sampai dengan 06 Oktober 2018 di Laboratorium Biologi Fakultas Ilmu Tarbiyah dan Keguruan Universitas Islam Negeri (UIN) Raden Fatah Palembang. Jenis penelitian ini adalah penelitian des kriptif kuantitatif (yang mana proses pengumpulan datanya menggunakan analisis statistik) dan dengan metode eksperimen (penelitian yang dilakukan untuk mengetahui pengaruh pemberian suatu treatment atau perlakuan terhadap subjek penelitian) (Yusuf, 2014).

Teknik Pengumpulan Data Teknik pengumpulan data menggunakan cara observasi langsung ke eksperimen. Metode yang digunakan dalam penelitian ini adalah metode eksperimen. Penelitian ini menggunakan Rancangan Acak Lengkap (RAL).

Prosedur penelitian

1. Persiapan Serangga Uji

Kutu beras ( Sitophilus oryzae) diambil dari tempat penyimpanan yang sudah dibiakkan (kurang lebih 30 hari) dengan cara memasukkan 10 pasang imago $S$. oryzae dalam 500 gram beras dan ditutup dengan kain kasa, untuk mendapatkan F1 kutu beras yang seragam yang masih muda dengan ciri berwarna coklat agak kemerahan. Kutu jantan dan kutu betina dapat dibedakan dari ukuran tubuhnya, kutu betina tubuhnya lebih besar dari kutu jantan (Wirdianti, 2015).

2. Membuat irisan dari beberapa kulit jeruk yang sudah dipilih (Moki $d k k, 2014$ )

Kulit jeruk yang dipilih yang masih segar, karena zat kimia yang terkandung didalamnya lebih banyak. Kemudian dibersihkan jika kotor selanjutnya diiris - iris sepanjang $2 \mathrm{~cm}$ dan selebar $0,3 \mathrm{~cm}$. Setelah diiris, siapkan kain kasa sebagai pembungkusnya dan masukkan kedalam kain kasa tersebut.

3. Uji Repellent (Kurniati, 2017). 
a. Meletakkan beras sebanyak 100 gram pada setiap stoples.

b. Memasukkan 20 ekor kutu beras hasil dari pembiakan yang telah dilakukan sehingga usia kutu beras yang digunakan homogen, lalu di aklimitasi selama 2 hari tanpa perlakuan agar kutu beras dapat menyesuaikan diri dengan lingkungan baru (toples uji yang digunakan).

c. Tiap perlakuan terdiri dari 2 toples yang dihubungkan dengan selang, dimana jarak selang dari permukaan beras sekitar $3 \mathrm{~cm}$, toples pertama merupakan toples yang akan diisi potongan kulit jeruk sesuai perlakuan dan toples kedua merupakan toples pengamatan tempat kutu beras akan berpindah yang berasnya tanpa diberi perlakuan (kontrol).

d. Masing - masing toples uji diberi label sesuai perlakuan.

e. Pada toples perlakuan, beras yang berisi 100 gram yang sudah ada kutu berasnya dimasukkan irisan kulit jeruk yang sudah terbungkus kain kasa dan diletakkan diatas beras posisinya ditengah beras dan agak terbenam sedikit.

f. Terakhir tutup toples dengan kain kasa untuk mencegah $S$. oryzae keluar.

g. Terakhir amati pada rentang 6 jam, 12 jam, 24 jam, 48 jam, dan 72 jam (Wirdianti, 2015).

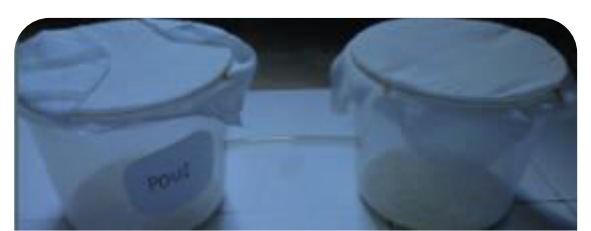

Gambar 1. Toples

(Sumber: Dok. Pribadi, 2018)

\section{HASIL DAN PEMBAHASAN}

\section{HASIL}

Pada penelitian pengaruh pemberian berbagai kulit jeruk sebagai repelensi kutu beras (Sitophilus oryzae L), dilakukan dengan mengaplikasikan irisan berbagai kulit jeruk dalam sebuah kantong kain kasa agar irisan kulit jeruk yang digunakan tidak mempengaruhi kualitas beras. Dari penelitian tersebut, diperoleh hasil penelitian berupa data jumlah kutu beras yang pindah pada masing-masing pengamatan untuk tiap perlakuan, kemudian diperoleh persentase penolakan kutu beras terhadap irisan berbagai kulit jeruk. Rata- rata persentase penolakan dapat dilihat pada tabel 3 berikut ini:

Tabel 1. Rata-Rata Persentase Penolakan Kutu Beras (Sitophilus oryzae L.) Tehadap Irisan Berbagai Kulit Jeruk

Perlakuan \% Penolakan

\begin{tabular}{llllll}
\hline & $\mathbf{L}_{\mathbf{1}}$ & $\mathbf{L}_{\mathbf{2}}$ & $\mathbf{L}_{\mathbf{3}}$ & $\mathbf{L}_{\mathbf{4}}$ & $\mathbf{L}_{\mathbf{5}}$ \\
\cline { 2 - 6 } Kontrol & 0 & 0 & 0 & 0 & 0 \\
Kulit Jeruk Manis & 5 & 11,25 & 18,7 & 25 & 35 \\
Kulit Jeruk Nipis & 2,50 & 16,25 & 25 & 47,5 & 56,25 \\
Kulit Jeruk Purut & 2,50 & 10,50 & 23,75 & 33,75 & 53,75 \\
Kulit Jeruk Lemon & 2,50 & 7,50 & 15 & 25 & 35 \\
Kulit Jeruk Bali & 1,25 & 7,50 & 13,75 & 22,50 & 31,25 \\
Kulit Jeruk Sunkist & 1,25 & 6,25 & 12,50 & 20 & 27,5 \\
\hline
\end{tabular}

Keterangan:

$\mathrm{L}_{1}=6$ jam

$\mathrm{L}_{2}=12$ jam

$\mathrm{L}_{3}=24$ jam

$\mathrm{L}_{4}=48$ jam

$\mathrm{L}_{5}=76$ jam 
Pada Tabel 1. dapat dilihat bahwa rata-rata persentase penolakan kutu beras terhadap irisan berbagai kulit jeruk terlihat nyata perbedaannya. Dapat dilihat bahwa irisan kulit jeruk nipis lebih efektif dalam menolak kutu beras (Sitophilus oryzae L.). Masing-masing perlakuan berbeda nyata dengan kontrol. Persentase penolakan tertinggi terdapat pada perlakuan kulit jeruk nipis yaitu sebesar 56,25 pada waktu 76 jam dan persentase terendah terdapat pada perlakuan irisan kulit jeruk sunkist yaitu sebesar 27,5 pada waktu 76 jam.

Berikut disajikan grafik rata-rata persentase penolakan kutu beras (Sitophilus oryzae L.) untuk semua perlakuan dan kelompok pengamatan, sebagai berikut :

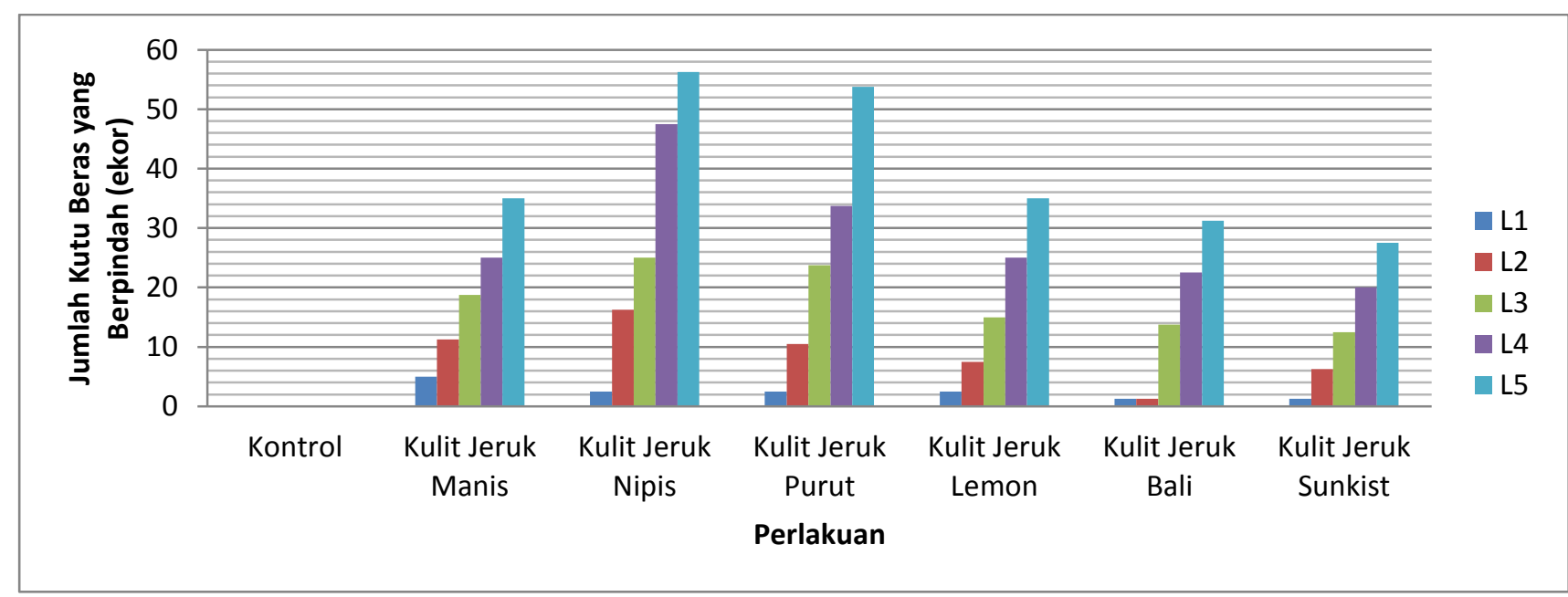

Grafik 1. Grafik Rata- Rata Persentase Penolakan Kutu Beras (Sitophilus Oryzae L.) Terhadap Berbagai Irisan Kulit Jeruk.

Terlihat dari grafik 1, bahwa rata-rata persentase penolakan kutu beras terjadi perbedaan antara perlakuan kulit jeruk yang satu dengan kulit jeruk yang lainnya. Pada masing-masing perlakuan terlihat perbedaannya nyata dengan perlakuan kontrol. Sedangkan untuk waktu atau lama pengaplikasian yang diamati, dapat dijelaskan bahwa semakin banyak kutu beras kutu beras yang pergi dari toples perlakuan.

Data hasil pengamatan pengaruh pemberian berbagai irisan kulit jeruk kemudian dilakukan analisis sidik ragam dengan pola RAL. Adapun hasil analisis tersebut dapat dilihat pada tabel 2 berikut ini: (Sumber: Hanafiah, 2016).

Tabel 2. Data Hasil Analisis Sidik Ragam (Ansira) RAL

\begin{tabular}{lcllll}
\hline \multicolumn{1}{c}{ SK } & DB & JK & KT & F Hitung & F Tabel \\
$\mathbf{1 \%}$ & & & & & \\
\hline $\begin{array}{l}\text { Ulangan } \\
\text { Perlakuan }\end{array}$ & 3 & 2806 & & & \\
\multicolumn{1}{c}{1,79} & 28909 & 850 & $19 * *$ & \\
Faktor A & 6 & 10651 & 1775 & $40^{* *}$ & 2,99 \\
Faktor B & 4 & 18052 & 4513 & $102 * *$ & 3,20 \\
Interaksi & 24 & 206 & 7,3 & $0,19^{\text {ns }}$ & 1,9 \\
Galat & 105 & 4515 & 44,2 & & \\
Total & 139 & 33424 & & & \\
\hline
\end{tabular}


KK $39 \%$

Keterangan :

$* *$ = Berbeda sangat nyata ( $\mathrm{F}$ Hitung $>1 \%$ )

$\mathrm{ns}=$ tidak berbeda nyata $(\mathrm{F}$ Hitung $<1 \%$ dan $5 \%$ )

Berdasarkan hasil analisis data diketahui bahwa $\mathrm{F}_{\text {hitung }}>\mathrm{F}_{\text {tabel, }}$ kecuali pada $\mathrm{F}$ hitung interaksi dimana nilai $\mathrm{F}$ hitungnya lebih kecil dari $\mathrm{F}$ tabel $(0,19<1,9)$. Sedangkan untuk $\mathrm{F}$ hitung perlakuan $(19>1,79)$ maupun $\mathrm{F}$ hitung Faktor A $(40>2,99)$ dan F hitung pada Faktor B ( $102>3,20)$, hal ini menyatakan bahwa irisan berbagai kulit jeruk (Citrus sp.) berpengaruh sangat nyata untuk menolak kutu beras (Sitophillus oryzae L.), sehingga dinyatakan bahwa $\mathrm{H}_{1}$ diterima dan $\mathrm{H}_{0}$ ditolak.
Terdapat juga perbedaan sangat nyata antar faktor A dan faktor B terhadap hasil penelitian. Untuk mengetahui perbedaan pengaruh dari masing-masing perlakuan dilakukan uji lanjut menggunakan Uji BJND (Beda Jarak Nyata Duncan) pada taraf $1 \%$. Adapun hasil Uji BJND faktor A dan faktor B, dapat dilihat pada tabel berikut:

Tabel Data Hasil Uji BJND (Beda Jarak Nyata Duncan) Pemberian Berbagai Kulit Jeruk Sebagai Repelent Kutu Beras (Sitophilus oryzae L.) Faktor A dan Faktor B.

Tabel 3. Data Hasil Uji BJND (Beda Jarak Nyata Duncan) Irisan Berbagai kulit Jeruk Sebagai Repelent Terhadap Kutu Beras (Sitophillus oryzae L.)

\begin{tabular}{llll} 
Perlakuan (Faktor A) & BJND & Perlakuan (Faktor B) & BJND \\
\hline P0 (ntrol) & a & L1 (6 jam) & A \\
P1 (Kulit jeruk manis) & b & L2 (12 jam) & B \\
P2 (Kulit jeruk nipis & c & L3 (24 jam) & C \\
P3 (Kulit jeruk purut) & c,d & L4 (48 jam) & D \\
P4 (Kulit jeruk lemon) & e & L5 (72 jam) & D \\
P5 (Kulit jeruk bali) & e,f & & \\
P6 (Kulit jeruk sunkist) & g & & \\
\hline
\end{tabular}

Keterangan: Huruf yang sama berarti berbeda tidak nyata (1\%) nyata $(1 \%)$

\section{Huruf yang tidak sama berarti berbeda}

Berdasarkan tabel 3. diketahui bahwa persentase penolakan irisan berbagai kulit jeruk terhadap kutu beras pada taraf $1 \%$ pada Uji BJND untuk tiap perlakuan menunjukkan huruf yang berbeda. Pada faktor A, yaitu banyaknya perlakuan irisan berbagai kulit jeruk. Dari perlakuan kontrol, irisan kulit jeruk manis 10 gr, irisan kulit nipis 10 gr, irisan kulit jeruk purut 10 gr, irisan kulit jeruk lemon 10 gr, irisan kulit jeruk bali 10 gr, dan irisan kulit jeruk sunkist 10 gr.

Didapatkan wilayah yang berbeda, kecuali P2 dan P3, serta P4 dan P5. Terdapat pada wilayah yang sama yaitu P2 dan P3 pada wilayah c dan pada P4 dan P5 pada wilayah e. Hal tersebut menunjukan perbedaan masingmasing perlakuan berbeda pengaruhnya terhadap perpindahan kutu beras.

Sedangkan pada faktor B, yaitu lama pengaplikasian irisan berbagai kulit jeruk 
didapat 4 wilayah berbeda dimana L1 diwilayah A, L2 diwilayah B, L3 diwilayah C dan L4 dan L5 diwilayah D. Jadi pengaruh waktu L4 dan L5 hampir sama terhadap perpindahan kutu beras dan berbeda dengan L1, L2 dan L3.

\section{PEMBAHASAN}

Persentase penolakan tertinggi terdapat pada perlakuan kulit jeruk nipis yaitu sebesar 56,25 pada waktu 76 jam dan persentase terendah terdapat pada perlakuan irisan kulit jeruk sunkist yaitu sebesar 27,5 pada waktu 76 jam.

Menurut Moki dkk (2014), jeruk nipis lebih banyak mengandung limonen yang lebih besar dan salah satu pembeda dari jeruk lainnya. Kandungan jenis senyawa limonen yang lebih besar dari jeruk lainnya menyebabkan laju yang berbeda dari kelima kulit jeruk diduga menjadi penyebab perbedaan pengusir $S$. oryzae. Limonene adalah racun kontak (contact poison) dan kemungkinan juga bekerja sebagai racun pernapasan (fumigants). Selain limonene jeruk nipis memiliki kandungan $\alpha$-pinene berperan sebagai toksin pada berbagai jenis serangga, dimana toksin ini menyebabkan gangguan pada system saraf yang berakibat terjadi paralisis, bahkan kematian pada serangga.

Selain itu, pada kulit jeruk nipis juga terdapat senyawa saponin. Saponin merupakan senyawa yang termasuk ke dalam senyawa terpenoid. Aktivitas saponin ini di dalam tubuh serangga adalah mengikat sterol bebas dalam saluran pencernaan makanan dimana sterol itu sendiri adalah zat yang berfungsi sebagai prekursor hormon ekdison, se-hingga dengan menurunnya jumlah sterol bebas dalam tubuh serangga akan mengakibatkan ter-ganggunya proses pergantian kulit (moulting) pada serangga. Selain itu, saponin bersifat bisa menghancurkan butir darah merah dan bersifat racun bagi serangga (Saleh dkk, 2017).

Berdasarkan penelitian sebelumnya bahwa yang lebih efektif sebagai reppelensi kutu beras yaitu kulit jeruk purut, menunjukan bahwa perlakuan kulit jeruk purut mengakibatkan persentase mortalitas pada Sitophilus oryzae yang cukup tinggi yaitu sebesar $48.333 \%$, di ikuti berturut-turut untuk perlakuan jeruk nipis dan jeruk manis sebesar 43.333\%, dan 35.833\%. (Moki dkk, 2014).

Mekanisme repelensi irisan berbagai kulit jeruk yang digunakan melalui lubang pernapasan karena irisan kulit jeruk masuk kedalam tubuh serangga melalui sistem pernapasan dalam bentuk gas karena serangga bernapas dengan sistem pernapasan yang disebut trakea. Oksigen tidak diedarkan melalui darah tetapi diedarkan melalui trakea (Hasanah dkk, 2012).

Menurut Aditama (2012) "dalam" Hasanah dkk (2012), cara kerja insektisida yang digunakan dalam pengendalian vektor terbagi dalam 5 kelompok, yaitu: mempengaruhi sistem saraf, menghambat 
produksi energi, mempengaruhi sistem endokrin, menghambat produksi kutikula, dan menghambat keseimbangan air dalam tubuh serangga. Mode of entry adalah cara insektisida masuk kedalam tubuh serangga, dapat melalui kutikula (racun kontak), alat pencernaan (racun perut), atau lubang pernapasan (racun pernapasan). Melalui dinding tubuh karena dinding tubuh serangga dapat menyebabkan insektisida dengan adanya lapisan epikutikula yang terdiri dari protein dan lemak. Insektisida juga dapat memasuki sistem pernapasan dalam bentuk gas ataupun butir-butir halus karena serangga bernafas dengan sistem tabung yang disebut trakea. Selain itu isektisida juga masuk ke alat pencernaan makanan serangga (usus) dan disinilah terjadi peracunan dalam jumlah yang besar.

Selain itu juga, berdasarkan hasil yang diperoleh bahwa kutu yang digunakan yaitu 10 Sitophilus oryzae L. jantan, dan 10 Sitophilus oryzae L. betina yang dilihat dari bentuk pisiknya bahwa Sitophilus oryzae L. jantan lebih kecil dari Sitophilus oryzae L. betina. Berdasarkan hasil bahwa Sitophilus oryzae L. jantan yang lebih banyak berpindah daripada Sitophilus oryzae L. betina dikarenakan masa lama hidup dan kekuatan fisik lebih lama yaitu imago betina $S$. oryzae 101 hari dan jantan 88,75 hari (Manueke dkk, 2015).

Pada pengamatan 6 jam perlakuan, rata-rata $\%$ penolakan tertinggi pada perlakuan irisan kulit jeruk nipis, yang kedua
Bioilmi Vol. 4 No. 2 Edisi Jufi-Desember Tahun 2018118 irisan kulit jeruk purut selanjutnya irisan kulit jeruk manis, irisan kulit jeruk lemon, irisan kulit jeruk bali, dan irisan kulit jeruk sunkist serta perlakuan yang terakhir tanpa diberi irisan kulit jeruk. Pada pengamatan 12 jam, 24 jam, 48 jam dan 72 jam perlakuan, ratarata $\%$ penolakan tertinggi juga terdapat pada perlakuan irisan kulit jeruk nipis. Hasil pengamatan tersebut, lama pengaplikasian irisan berbagai kulit jeruk menunjukkan persentase penolakan rata-rata tertinggi yaitu perlakuan irisan kulit jeruk nipis dengan ratarata persentase penolakan 56,25\%.

Dalam kulit jeruk terdapat senyawa flavonoid. Menurut Tarigan dkk (2012), senyawa flavonoid yang merupakan salah satu jenis senyawa yang bersifat racun sehingga dapat dimanfaatkan sebagai insektisida nabati. Flavonoid mempunyai sifat yang khas yaitu bau yang sangat tajam, sebagian besar merupakan pigmen warna kuning, dapat larut dalam air dan pelarut organik, mudah terurai pada temperatur tinggi.

Kandungan saponin dan polifenol pada irisan kulit jeruk tersebut bekerja sebagai racun perut dan racun pernafasan. Sebagai racun pernafasan, zat tersebut dapat meracuni melalui saluran pernafasan yang ada di permukaan tubuh yang kemudian masuk ke dalam tubuh. Sedangkan kandungan saponin dapat menyebabkan destruksi (kerusakan) saluran pencernaan dengan cara menurunkan tegangan pada permukaan sehingga selaput mukosa saluran pencernaan menjadi korosif. Hal tersebut menyebabkan manurunnya 
aktivitas enzim pencernaan dan pencernaan makanan (Tarigan dkk, 2012).

Berdasarkan hasil analisis data diketahui bahwa $\mathrm{F}_{\text {hitung }}>\mathrm{F}$ tabel, kecuali pada $\mathrm{F}$ hitung interaksi dimana nilai $\mathrm{F}$ hitungnya lebih kecil dari $F$ tabel $(0,19<1,9)$. Sedangkan untuk F hitung perlakuan ( $19>$ 1,79) maupun F hitung Faktor A $(40>2,99)$ dan F hitung pada Faktor B ( $102>3,20)$, hal ini menyatakan bahwa irisan berbagai kulit jeruk (Citrus sp.) berpengaruh sangat nyata untuk menolak kutu beras (Sitophillus oryzae L.), sehingga dinyatakan bahwa $\mathrm{H}_{1}$ diterima dan $\mathrm{H}_{0}$ ditolak.

Selanjutnya diperoleh nilai KK (koefisien keragaman) $39 \%$ sehingga dilakukan uji lanjut BJND (Beda Jarak Nyata Duncan) untuk mengetahui perbedaan pengaruh dari masing-masing perlakuan. Berdasarkan hasil uji BJND (Beda Jarak Nyata Duncan) pada tabel 5, menunjukkan bahwa taraf $1 \%$ pengaruh irisan berbagai kulit jeruk sebagai repelent kutu beras (Sitophillus oryzae L.) untuk mengetahui perbedaan antara satu perlakuan ke perlakuan lainnya. Karena F hitung interaksi tidak ada, maka uji BJND (Beda Jarak Nyata Duncan) dilakukan terpisah antara faktor A dan Faktor B. Hasil uji BJND (Beda Jarak Nyata Duncan), baik faktor A maupun faktor B memiliki perbedaan dilihat dari wilayah yang berbeda. Hal tersebut menunjukkan bahwa irisan berbagai kulit jeruk dari berbagai perlakuan serta waktu pengaplikasian memiliki pengaruh yang berbeda dalam menolak kutu beras (Sitophillus oryzae L.).

\section{KESIMPULAN}

Dari hasil penelitian yang telah dilakukan mengenai Pengaruh Pemberian Berbagai Kulit Jeruk sebagai Repelensi Kutu Beras (Sitophillus oryzae L.), maka dapat diambil simpulan bahwa irisan berbagai kulit jeruk efektif sebagai repelent kutu beras (Sitophilus oryzae L.). Hal ini berdasarkan persentase penolakannya, persentase penolakan tertinggi terdapat pada perlakuan kulit jeruk nipis yaitu sebesar 56,25 pada waktu 76 jam dan persentase terendah terdapat pada perlakuan irisan kulit jeruk sunkist yaitu sebesar 27,5 pada waktu 76 jam. Berdasarkan uji ANOVA taraf 1\% F hitung > F tabel yaitu untuk $F$ hitung perlakuan $(19>1,79)$; F hitung faktor A $(40>2,99)$; dan F hitung faktor B $(102>3,20)$.

\section{UCAPAN TERIMA KASIH}

Segala puji dan syukur peneliti panjatkan kehadirat Allah SWT yang telah melimpahkan rahmat dan hidayah-Nya. Pada kesempatan ini, Peneliti tidak lupa mengucapkan terima kasih yang sebesarbesarnya kepada semua pihak yang telah membantu.

\section{DAFTAR PUSTAKA}

Adrianto, H., Subagyo, Y., \& Hamidah. (2014). Efektivitas Ekstrak Daun Jeruk Purut (Citrus hystrix), Jeruk Limau 
(Citrus amblycarpa), dan Jeruk Bali (Citrus maxima) Terhadap Larva Aedes aegypti. Vol. 6. No. 1.

Anggara, A. W \& Sudarmaji. (2009). Hama

Pascapanen Padi dan Pengendaliannya.

Jakarta: Balai Besar Penelitian Tanaman Padi.

Al- Qur'an Al- Karim. (2010). Al- Qur'an dan

Terjemahannya. Bandung: CV.

Diponegoro.

Dadang \& Djoko Prijono. (2011).

Pengembangan Teknologi Formulas!

Insektisida Nabati Untuk Pengendalian

Hama Sayuran Dalam Upaya

Menghasilkan Produk Sayuran Sehat.

Jurnal llmu Pertanian Indonesia. Vol. 16.

No. 2. ISSN 0853- 4217.

Fajarwati, D., Toto, H., \& Ludji, P. A. (2015).

Uji Repelensi Ekstrak Daun Jeruk Purut

(Citru hystrix) Terhadap Hama Beras

Sitophilus oryzae L. (Coleptera :

Curculionidae). Jurnal HPT. Vol. 3. No.

1. ISSN: 2338-4336.

Guswenrivo, I., Tarmadi, D., \& Yusuf S. (2013). Aktivitas Insektisida Ekstrak Buah Bintaro ( Cerbera manghas) Terhadap Kutu Beras (Sitophilus pryzae) (Coleptera : Curculionidae) (Insecticide Activity of Cerbera manghas Fruit Extract to Sitophilus oryzae (Coleptera : Curculionidae)). Jurnal \& Teknologi Kayu Tropis. Vol. 11. No. 1.

Hanafiah, K.A. (2016). Rancangan Percobaan Teori dan Aplikasi. Jakarta: Rajawali Pers.
Bioilmi Vol. 4 No. 2 Edisi Juli-Desember Tahun 2018120

Hasanah, M., I Made, T., \& Jamaludin, S. (2012). Daya Insektisida Alami Kombinasi Perasan Umbi Gadung (Dioscorea Hispida Dennst) Dan Ekstrak Tembakau ( Nicotiana Tabacum L). ISSN 2302-6030.

Hendrival \& Lilis, M. (2017). Pengaruh Kepadatan Populasi Sitophilus oryzae (L.) Terhadap Pertumbuhan Populasi dan Kerusakan Beras. Jurnal Biospecies. Vol. 10. No. 1.

Hutabarat, L. N. (2010). Penngendalian Sitophilus oryzae (Coleoptera: Curcullionidae) dan Tribolium castaneum (Coleptera: Tenebrionidae) dengan Beberapa Serbuk Biji Sebagai Insektisida Botani. Jurnal Intra. Vol. 5. No. 2.

Indiati \& Marwoto. (2008). Potensi Ekstrak Biji Mimba Sebagai Insektisida Nabati. Jurnal Palawija. No. 15.

Irfan, M. (2016). Uji Pestisida Nabati Terhadap Hama dan Penyakit Tanaman. Jurnal Agroteknologi. Vol. 6. No. 11.

Istianto., K. Untung., Mulyadi, Y. A. Trisyono., \& T. Yuwono. 2006. Komposisi dan Konsentrasi Senyawa dalam Minyak Atsiri Jeruk Manis dan Jeruk Besar terhadap Perkembangan Tungau Panonychus citri McGregor. Jurnal Hort. Vol.16. No. 1.

Lestari Indah, Syamsul Rizal \& Dian Mutiara. (2010). Uji Toksisitas Akut Serbuk Kering Daun Sirsak (Annona Muricata Linn.) Terhadap Kutu Beras (Sitophilus Oryzae L.). Vol. 7. No. 2. 
121 Bioilmi Vol. 4 No. 2 Edisi Jufi-Desember Tahun

Manaf, Syalfinaf., Eti Kusmini., \& Helmiyetti. Evaluasi daya repelensi daun Nimba (Azadirachta indica A. Juss)terhadap hama gudang Sitophilus oryzae L. (Coleoptera : Curculionidae). Jurnal Gradien. Vol. 1. No. 1. ISSN : 0216- 2393.

Manueke, J., Max T., \& J.M.E., Mamahit. (2015). Bilogi Sitophilus oryzae dan Sitophilus zeamais (Coleoptera:

Curculionidae) Pada Beras Dan Jagung Pipilan. Vol. 21. No. 1.

Manueke, J., Max, T., Pelealu., \& Paat. (2012). Tabel Hidup Sitophilus oryzae (Coleoptera: Curculionidae) Pada Beras. Vol. 18. No. 1.

Moki, M., Rida, I \& Fahria D. 2014. Uji Efektivitas Tiga Jenis Kulit Jeruk Sebagai Insektisida Nabati dalam Menekan Populasi dan Serangan Kumbang Beras (Sitophilus oryzae). Universitas Negeri Gorontalo.

Pracaya. 1993. Jeruk Manis Varietas Budaya dan Pascapanen. Jakarta: PT Penebar Swadaya.

Prastiwi, S \& Ferry, F. (2016). Kandungan dan Aktivitas Farmakologi Jeruk Nipis (Citrus aurantifolia). Jurnal Agroteknologi. Vol. 6. No. 2. ISSN: 2087-0620.

Rukmana. (2003). Uji Efektivitas Jeruk Manis dan Larutan Daun Nimba Untuk mengendalikan Spodoptera Litura F. (Lepidoptera: Noctuidae) Pada Tanaman
Sawi di Lapangan. Jurnal Online Agroekoteknologi. Vol. 1. No. 1.

Saleh, M., Andi S., Syarfaini., \& Musdalifah. (2017). Uji Efektivitas Ekstrak Kulit Buah Jeruk Nipis (Citrus aurantifolia) Sebagai Insektisida Hayati Terhadap Nyamuk Aedes aegypti. Vol. 3. No. 1. ISSN : 2541-5301.

Sari, M., Lahmudin, L., \& Yuswani, P. (2013). Uji Efektivitas Beberapa Insektisida Nabati Untuk Mengendalikan Ulat Grayak (Spodoptera Litura F.) (Lepidoptera : Noctuidae) Di Laboratorium. Jurnal Online Agroekoteknologi. Vol.1, No. 3. ISSN No. 2337- 6597.

Saputra, K. A. (2017). Kandungan Kimia Minyak Atsiri dari Kulit Buah Jeruk Bali (Citrus maxima) Serta Uji Aktivitas Antibakteri Terhadap Staphylococcus aureus dan Eucherichia coli. Jurnal Kimia. Vol. 11. No. 1. ISSN: 1907-9850. Sarwono. (2001). Khasiat dan Manfaat Jeruk Nipis. Tangerang: PT Agro Media Pustaka.

Siregar, A.Z. (2016). Literasi Inventarisasai Hama dan Penyakit Tembakau Deli Di Perkebunan Sumatera Utara. Jurnal Pertanian Trofik. Vol. 3. No. 3. ISSN: 2356-4725.

Steenis, G.G. J. V. (1992). Flora. Jakarta: PT. Pradny Paramita.

Yudansha, A., Toto, H., \& Ludji, P.A. (2013). Perkembangan dan Pertumbuhan Sitophilus oryzae L. (Coleptera : 
Curculionidae) Pada beberapa Jenis Beras

Dengan Tingkat Kelembaban Lingkungan Yang Berbeda. Jurnal HPT. Vol. 1. No. 3.

Yusuf, Muri. (2014). Metode Penelitian.
Bioilmi Vol. 4 No. 2 Edisi Juli-Desember Tahun 2018122

Wirdianti, S. (2015). Pengujian Beberapa Jenis Insektisida Nabati Terhadap Kutu Beras (Sitophilus oryzae L). Jurnal Biota. Vol. 1. No. 1.

Jakarta: Prenadamedia Group. 